\title{
Women hawkers in Tehran's metro: everyday politics and the production of public space
}

\begin{abstract}
Tehran's metro symbolises the city's claims to world-class status and its expansion enjoys widespread support across the political spectrum. This article focuses on the ways in which the carriages reserved for women are appropriated by female hawkers despite the efforts of municipal officials determined to eliminate hawking within the metro. On an everyday basis, the ubiquity of hawkers contributes to the production of a convivial atmosphere within the carriages reserved for women. However, the surreptitious appropriation of space comes at a cost for the hawkers, who face competing pressures. While this space is emancipatory in the sense that it is a relatively safe place for female hawkers to earn their livelihoods or spending money, many have reported feelings of anxiety because of the stigma associated with hawking. This article contributes to the scholarship on urban citizenship and exclusion by focusing on the governance of a 'world-class' urban megaproject, and the complex social and economic pressures that affect some of its users.
\end{abstract}

Keywords: Tehran, informality, women's empowerment, inequality, urban governance

\section{Introduction}

Tehran's metro was inaugurated in 1999, and currently boasts $132 \mathrm{~km}$ of track and ninety-five stations, with plans to add a further i $10 \mathrm{~km}$ in coming years at a cost of $\$ 6$ billion. This project is emblematic of ongoing efforts in cities throughout the global South to transform cityspace and create 'world-class' spaces through public and private investment in infrastructure and real estate. Such plans are often accompanied by the imposition of governance regimes that strictly regulate how and by whom urban space is used. Scholars have focused on the anti-poor nature of these regimes, and the ways in which informal-sector workers whose livelihoods depend on access to space are criminalised and dispossessed of workspace. This article contributes to the scholarship by examining how female hawkers use 'world-class' space after it has been transformed - i.e. Tehran's metro - despite the efforts of the authorities to curb their operations. We focus on female hawkers who operate in the carriages reserved for women in Tehran's metro. We relate this research to recent scholarship that examines the relationship between place and identity, and show that the women's use of space is enabled by passengers who engage in calculated acts of defiance. However, for some women the appropriation of space comes at a personal cost because working as a hawker challenges their claims to membership of the middle class. This article shows 
that rather than bureaucratic notions of membership in a nation state, citizenship plays out at the urban scale as people struggle to remain and make lives for themselves in cities (see Yiftachel, 20I5; Blokland et al., 2015; Weinstein, 2014). Thus, rather than an abstract notion of belonging in an imagined community, we embrace Yiftachel's (2015) conceptualisation of 'metrozenship', which is grounded in concrete struggles over access to urban space.

Street hawkers are particularly vulnerable to efforts to regulate and transform urban space because they tend to work in strategic locations with a high volume of pedestrian traffic. In many instances, these are the very places where the authorities seek to impose and showcase a 'world-class' urban vision, which involves the exclusion of 'undesirable' users such as street dwellers and hawkers. In response, street hawkers adapt their practices in order to maintain access to space - and hence their livelihoods - in the context of urban transformation and revanchist governance regimes. Thus, cities are often conceptualised as veritable chess boards whose spaces are fought over in a series of zero-sum contestations, the results of which determine whether space remains accessible to street hawkers and other informal-sector workers. An important question remains: Does 'world-class' urban space remain permanently inaccessible to street hawkers and other informal service-sector workers, or can they adapt and learn how to operate within - and appropriate - these spaces in spite of physical and institutional barriers?

The extent to which street hawkers and other informal service-sector workers can access 'world-class' urban space is an important question given the scope of urban transformation in many cities in the global South. Entirely new districts are springing up on the peripheries of many metropolises and vast metropolitan areas are being interwoven with state-of-the-art rapid transit systems. The ability of street hawkers (and other informal service-sector workers) to adapt and operate within these spaces will determine the extent to which (I) the city remains liveable for the majority of its residents and (2) visions of urban transformation are ultimately realised. We speak to these issues by answering two interrelated questions: first, How do female hawkers operate within Tehran's metro despite the authorities' aggressive attempts to curtail their activities? Second, How does the hawkers' presence contribute to the lived space within the metro? We show that hawkers develop an understanding of the metro and engage in localised city learning 'from below' (Bradlow, 20I5; McFarlane, 20I I). Their use of the metro is aided by fleeting cross-class alliances with more affluent passengers, for whom assisting hawkers is a calculated act of defiance against a regime that has sought to foreclose political dissent. Commerce, consumption and defiance cohere into a complex 'everyday process of interpersonal interaction that produces new relations, trajectories and representations and which dynamically reconfigures power asymmetries' (Alff, 20I5, 25I). However, despite the solidarity that emerges as a response to the imposition of a restrictive governance regime, hawkers reported 
a deep sense of anxiety surrounding their class position because the occupation is considered anathema to claims of membership of the middle class.

We present empirical evidence drawn from participant observation and ten interviews conducted in Tehran's metro with female hawkers and another with a security guard in February and March 20I4. Ethnographic descriptions are drawn from participant observation as a customer of the hawkers and a passenger in the metro. In the next section, we review the literature on urban transformation in Southern cities focusing on the ways in which infrastructure projects entrench inequality, with particular attention to scholarship on street hawkers. In the third section, we present empirical evidence from Tehran. In the fourth section, we explore everyday politics, citizenship, the use of public space and the production of 'world-class' cityspace. Finally, we conclude and elaborate on the implications of this case for future research.

\section{Urban transformation, inequality and exclusion}

Cities in the global South are undergoing rapid transformation. Aihwa Ong refers to these purposeful efforts to transform cities as 'worlding practices', which she defines as 'constitutive, spatializing, and signifying gestures that variously conjure up worlds beyond current conditions of urban living' (201 I, I3). Many municipal governments practice 'worlding' by embracing ambitious plans to transform urban built environments into 'world-class' cityscapes (Lindell and Appelblad, 2009; Dupont, 20II; Goodfellow and Smith, 20I3; Watson, 2013; Kleibert and Kippers, 2016). Schindler (2015) has argued that urban transformation has become the overriding objective of many municipal governments, to which the secondary goal of 'improving' populations - most notably the poor - has been subordinated. While many of these ambitious plans to transform cities are never realised in toto (Goodfellow, 20I3; Roy, 2009), attempts to comprehensively transform urban space nevertheless impact the built environment of cities and the everyday lives of residents. For example, Vanessa Watson refers to recent plans to transform African cities as 'fantasies' which:

[A]re unlikely to materialize, yet the efforts to achieve them will have profound effects on lives and livelihoods. While those with a degree of power and resources may well be able to benefit in various ways, given the overwhelming dominance in African cities of those with very little, a widening and deepening of inequality is inevitable. (2013, 229)

Socio-economic inequality in many Southern cities is directly related to urban transformation because rapid population growth has been unaccompanied by concomitant industrialisation in many cities in the global South (Fox, 2014; Chen and Skinner, 20I4), and capital is more likely to be invested in real estate or built infrastructure than industrial production (Schindler, 2015). This has left many urban residents unable to sell their labour power for a wage, and as a result they remain outside of 
imagined communities whose membership has historically been tied to production (Sanyal, 2007; Li, 2010; Davis, 2007; Ferguson, 2015). While some places are aggressively transformed into 'world-class' post-industrial spaces for productive and affluent residents to live and consume, large swaths of territory are informally planned and more or less devoid of public services such as piped water, sewerage and waste collection (Roy and Alsayyad, 2004; Gandy, 2004; Fernandez, 20I4; Schindler and Kishore, 20I5). Inequality has been indelibly etched into fragmented cityscapes as 'world-class' spaces of luxury living and consumption are interwoven with informal settlements (Graham and Marvin, 200I), and in many cities it is not entirely clear which 'type' of space will ultimately represent the city. In some cases, secure and connected 'worldclass' spaces resemble archipelagos in a sea of informality (Bakker, 2003; Caldeira, 2000), while elsewhere the existence of informal cityscapes is directly threatened by formal urban transformation (Harms, 20I2; Ramakrishnan, 20I4; Shatkin, 20II; Bunnell, 2002; Robinson, 2006). In both instances, questions surrounding access to urban space and services are paramount. For example, China's 'great urban transformation' (Hsing, 20I0) has been accompanied by considerable confusion over how to manage the integration of the country's 'floating' population into rapidly growing cities. Responses from municipal authorities have ranged from selling more affluent migrants the paperwork required to settle in the city, to the forceful eviction and rendition of migrants to their rural residences (Solinger, I999; for governance of street hawkers see Xue and Huang, 2015). Elsewhere the poor cannot be evicted, so municipal authorities seek to exclude them from urban space and services. In the case of South Africa, for example, the wave of post-apartheid service delivery protests amounts to a 'rebellion of the poor' characterised by persistent challenges to urban South Africa's fortressed and highly unequal cityscape (Alexander and Pfaffe, 20I3).

Struggles over access to urban space in the context of urban transformation are subject to a considerable amount of contingency. In many instances, the poor assert their right to the city and manage to maintain access to the places where they live and work (Weinstein and Ren, 2009; Schindler, 20I4a; Weinstein, 20I4; Chatterjee, 2004; Soliman, 2004; Silver, 20I4). Benjamin (2008) has shown how international finance capital struggles to penetrate the dense social webs at the neighbourhood scale that actually determine how and by whom urban space is used. Alternatively, Bayat (2000) has shown how urban space and resources are surreptitiously appropriated through incremental 'quiet encroachment'. According to Bayat, this quiet encroachment is the sum total of a multiplicity of quotidian practices, a state of affairs that he terms a non-movement which:

$[R]$ efers to the collective actions of noncollective actors; they embody shared practices of large numbers of ordinary people whose fragmented but similar activities trigger much social change, even though these practices are rarely guided by an ideology or recognizable leaderships and organizations. (2010, I4) 
Scholarship on street hawkers has shown that they are under political and economic pressure, as they are aesthetically inconsistent with attempts to transform urban space and hence they are consistently threatened with eviction. As such, in many cities they are engaged in struggles over access to the places where they have historically operated (Anjaria, 2009; Turner and Schoenberger, 2012; Bell and Loukaitou-Sideris, 2014; Asiedu and Agyei-Mensah, 2008; Crossa, 2009). In many instances, legislation has eroded the ability of street hawkers to make claims to space. For example, hawkers' associations in Kampala have been weakened by the privatisation of markets (Lindell and Appelblad, 2009), while court rulings in India have reversed earlier decisions which safeguarded hawkers' use of urban space if eviction would eliminate their livelihoods (Schindler, 2014b). Ethnic, class and gender discrimination often intersect in the context of anti-hawking governance. In the case of Ecuador, indigenous people were disproportionately impacted by anti-hawking drives (Swanson, 2007), while in Mexico City hawkers from more affluent backgrounds were less likely to draw unwanted attention from the authorities than their poorer counterparts (Crossa, 2016).

In sum, the literature shows that street hawkers are considered a threat to municipal efforts to transform cityspace, and hence they are routinely engaged in struggles over urban space and efforts to police the boundaries of urban citizenship. However, scant scholarship has examined the extent to which they are able to access and make use of urban space after it has been transformed (e.g. exclusive gated communities, shopping centres, sports stadia and metro stations). The limited scholarship that does focus on the governance of these spaces suggests that municipal governments struggle to adapt regulatory institutions to the rapid pace of urban transformation. For example, in the case of the high-rise apartment buildings that are mushrooming across Jakarta, Abdoumaliq Simone has shown that 'the regulatory apparatus of local government is not geared to this form of high-rise living and can do little about what takes place inside these complexes' $(2014,70)$. The uncertainty and fluidity that characterises the order of things in Jakarta's exclusive high-rises and the challenge they pose to municipal efforts to regulate space indicates that they may foster rather than foreclose contingency. Indeed, C. P. Pow has argued against the portrayal of gated communities as inherently dystopian, and called for a 'more complex, situated understanding of gated communities that reveals not only cases of exclusion and polarization but also spaces of indeterminacy and contingencies that challenge and unsettle dominant assumptions and notions of the singularity of the power of private property and urban spaces' (2015, 48I).

In this article we seek to shift the gaze away from struggles over urban space that is in the process of being transformed, and instead focus on everyday life and politics within space that has already been drawn into an ambitious programme of urban transformation. Our research demonstrates that a 'world-class' city vision is not necessarily enshrined in these spaces through strict control and surveillance. Instead, such space can be appropriated and transformed into authentic public space produced 
through negotiation and everyday acts of performed, incremental encroachment (see Orum et al., 2009; Qian, 20I4). In Tehran's metro the women's carriages become 'safe havens' (Anguelovski, 20I3) for female hawkers to earn livelihoods and pocket money. The widespread practice of hawking contributes to the production of vibrant public space, which is defended by passengers who help hawkers avoid security crackdowns. The production and use of public space must, however, be reconciled with the impact it has on the identity of those who produce/use it. We demonstrate that for women working as hawkers, the use of public space disrupts deeply held notions regarding their class position because there is a social stigma associated with hawking. Thus, they challenge municipal efforts to produce space and are able to earn livelihoods, but this comes at a cost because they are forced to stake a claim to an inferior class position.

\section{Hawking in Tehran's metro}

Iran's post-revolutionary leadership consolidated power shortly after the I979 revolution, yet Iranian society remains highly politicised. While scholarship and the media have commonly focused on electoral politics and dramatic confrontations such as the mass demonstrations in 2009, Iranians practice everyday politics and mobilise in a range of spaces (Fadaee, 2012). Everyday politics in Tehran remains vibrant and fluid, and Tehran's metro is an example of how public space is produced through its performance and practice. It was planned prior to the I979 revolution which resulted in the overthrow of the last Shah of Iran, Mohammad Reza Pahlavi. While plans to build the metro were supported by Iran's post-revolution leadership, construction was postponed because of the onset of war with Iraq in I980. Construction was resumed in 1995 and the first line was inaugurated four years later, with extensions that continue to date. The expansion of the metro is necessitated by Tehran's rapid growth and it has symbolised Iran's ability to undertake extensive development projects despite ongoing economic sanctions. Its unique history, practical use-value and symbolic power mean that the expansion of Tehran's metro enjoys widespread support across the political spectrum, from the conservative establishment to progressive reformists.

\section{Class, gender and livelihoods}

Tehran's metro has separate carriages for women travelling unaccompanied by men. This gendered division of space reconciles the goal of producing a circulating population (Foucault, 2007) with the Islamic leadership's imperative of maintaining the chastity of women. However, women easily appropriate this space in multiple and unanticipated ways as most security personnel in the metro are male and cannot enter carriages reserved for women. On an everyday basis, many women take advantage of the limited ability of the authorities to exert control over this space to engage in 
symbolic acts such as removing their headscarves or applying cosmetics to risky acts of outright resistance such as dancing. One young woman uploaded a video of herself dancing in the metro to a popular website, and it captured the attention of Iranians and Western media alike. ${ }^{\text {' }}$

The most common way in which women illicitly use this space is to hawk a variety of items including food, cosmetics and fashion accessories, children's toys, home décor and clothing. Most passengers who purchase items from hawkers do so because they can use them rather than from any sense of charity, so hawkers must respond to market forces. Most source their inventory from wholesalers in the Grand Bazaar, the border regions or the southern islands of the Persian Gulf. Others sell their own handcrafted products or homemade food such as snacks and cookies. All the hawkers interviewed reported operating on small margins and their livelihoods therefore depend on selling a high volume of goods. Some female hawkers only work seasonally, and travel to Tehran from surrounding towns and villages temporarily at certain times of the year, such as the run-up to Nowruz (the Iranian New Year), when they are certain of significant demand for their products. However, the majority of the women interviewed are permanent Tehran residents. Interestingly, they all claimed that they had never worked as a hawker on the streets of Tehran. The metro has created a unique opportunity because hawking offers a relatively predictable income and flexible hours. They also agreed that it was easy to take up because it does not require significant financial resources. Some of the women reported being the main breadwinner in their household, which means that hawking in the metro offers an indispensable livelihood. For example, one woman explained:

I have kidney problems, I cannot work all the time. My husband is also paralysed. I have three kids. In people's houses it was more difficult to work [as a domestic servant], here is easier. (Personal communication, 2014)

Similarly, another woman who had previously worked as a hospital nurse explained that hawking in the metro was preferable to home care:

I liked working in the hospital more because it was a meaningful job. But because I got older they did not want me anymore. After I left the hospital I was working as a nurse at homes but then I had some difficulties to work with ill people, then I changed my job and decided to work in the metro. (Personal communication, 20I4)

Many of the women explained that they chose to take up hawking in the metro because the women's carriages provide a safe work environment where, in comparison to city streets, they are less likely to be harassed by the authorities or male passers-by. One woman explained:

I http://www.npr.org/blogs/thetwo-way/20I4/I I/28/367I83760/video-of-woman-dancing-on-tehrans-subwaygoes-viral (accessed I7 March 2015). 
You are more or less secure and sure that at the end of the day you earn something. I have done many different jobs. For example, I got a job offer as a secretary, with good money and flexible working time, but there was something else behind it. The boss had other interests. So I did not accept it. Here among women I am safe, I work whenever I want, if for example my child is sick, I can stay home. (Personal communication, 20I4)

It is clear that hawking in the metro is an important source of livelihood and it is preferable to formal-sector employment where women are forced to work inflexible hours or can be subject to harassment. Working in public space as a hawker is emancipatory in the sense that it allows women to manage their time and relations. However, working as a hawker comes at a cost because it is generally considered a low-class occupation. As a result, it forces many of the women to question deeply held notions of class and social status. Hawking has indeed historically been an occupation that attracted poor or lower middle-class individuals. However, the majority of the women working in the metro did so part-time and were either housewives who sought to supplement their household income or university students. These women took great pains to distinguish themselves from their poorer counterparts on the city's streets and in its bazaars, and to demonstrate their affinity with more affluent passengers. For example, one woman who sold accessories that she crafted herself explained that she is simply a shopkeeper without a shop:

Someone who sees this job from below might think, 'Oh, this is hawking', but actually I feel I am a shopkeeper without a shop. I could also rent a shop and sell my work there but I don't do it because there is no point in doing it. Here in the metro I am very comfortable. (Personal communication, 2014)

Many of the women complained that there continues to be stigma attached to hawking. One claimed to be a university student and emphasised that she was only hawking temporarily and would soon transition into a professional career:

Some [passengers] are not nice at all. They think the world has come to an end for us and that is why we are doing this job. They see themselves as higher than us. Some of them are even less educated than us but they don't see it. After I graduate this term I will do the lawyer exam and there will be no need for me to work here anymore.

(Personal communication, 2014)

Another hawker complained about the fact that some people show interest in their personal stories - a thinly veiled criticism of this research - and imply that they are a curiosity and in need of charity. She acknowledged that many hawkers are indeed in need of charity, but she sought to distinguish herself from them:

I think people should also help the hawkers economically [instead of doing research]. I am not saying it for myself. My husband is a taxi driver and he earns good money. I 
just work to earn some extra money for the family. But there are women who are really in need of the money they earn. What I am saying is that by just asking questions and leaving, their situation will not change. I hope you realise I am not saying it for myself.

In sum, there is a sense of empowerment among female hawkers working in Tehran's metro, as they are able to earn a secure livelihood or supplemental income independently. However, working as a hawker provokes a sense of unease because they consider it a low-class occupation, and this has forced many hawkers to question deeply held assumptions regarding their supposed middle-class identity. In addition to influencing the livelihoods and class position of individual hawkers, the practice of hawking in Tehran's metro has transformed the women's carriages into vibrant spaces. It is to this production of space that we turn in the following section.

\section{Producing public space}

Hawkers operate in Tehran's metro throughout the day, and their interaction with passengers contributes to a convivial atmosphere within the women's carriages. These carriages become public spaces where passengers exchange commodities, money and ideas. Hawkers demonstrate the utility and value of their goods, and the merits and drawbacks of the goods offered become the topic of public discussion. Through these lively exchanges the women's carriages in Tehran's metro are transformed from an instrumental mode of transportation to a convivial mobile market.

Hawkers often board a train with their wares concealed in a shopping bag. Once the train departs the station, they distribute a number of items to passengers throughout the compartment and then circulate, extolling the virtues of their products. Next, they collect their merchandise and conduct transactions should a passenger choose to purchase an item. The hawkers explained that most of the passengers participate by examining the items for sale. One person might say that she has already bought and used an item and recommend it to other passengers. If hawkers sell food, passengers who buy and try it often loudly express their approval or dissatisfaction. In summary, hawkers and their goods generate sociality among passengers who would otherwise most likely not communicate with one another, and the majority of passengers seem to value their presence. The lengthy discussions regarding the virtues or shortcomings of items offered by hawkers demonstrate that most customers purchase goods because of their appeal rather than out of a sense of charity to the hawkers.

Many of the hawkers operate in accordance with an understanding of the negotiated nature of public space. For example, one woman stated that she tried to target passengers who expressed interest in her products without disturbing others:

By just entering the metro I think we are bothering the passengers $[\ldots]$ Look, people are coming back from work, they are tired or [if] they are students and want to study 
they will be distracted. Many hawkers are loud and make a lot of noise but I personally pay attention to the passengers. (Personal communication, 2014)

Passengers often enable hawking by alerting hawkers when security personnel are enforcing anti-hawking rules at a particular station. This assistance is crucial because hawkers are most vulnerable when disembarking a train. Since male security guards cannot enter the carriages reserved for women their main method of enforcing antihawking rules is to position themselves on the platform near the exits of the train. There they try to identify women who were hawking on the train by scrutinising their baggage. Hawkers typically ride a train for a few stations and then disembark and board another. Thus, they must change trains many times in the course of a day, and with advanced knowledge of security operations they can simply avoid stations in which security personnel are operating on the platforms. Alternatively, if they must transit through a particular station where security is in place, they can ensure that their wares are adequately concealed or disguised as personal items.

Hawkers are rarely caught by security guards, yet this is nevertheless the primary risk they face on a daily basis. Security guards can seize their goods, and the authorities can levy a fine. One woman who sold chewing gum and chocolates was caught by security on a platform when she was switching trains because she was carrying a display tray. She explained that 'Some days ago they took my stuff, I cried so much and begged them to give me my stuff. Then I started quarrelling with them [...] I have nothing to lose' (Personal communication, 20I4).

It is not a foregone conclusion that hawkers who are caught by security guards will have their goods confiscated because enforcement of anti-hawking rules varies considerably from case to case. The extent to which the authorities should enforce anti-hawking ordinances became more politicised in January 2014 when a young man suspected of hawking in the metro was pursued by security guards and ultimately struck and killed by an oncoming train. The incident attracted significant media attention in Iran and provoked controversy because it was unclear whether he was pushed, fell or purposefully jumped from the platform. Prior to this incident, municipal authorities had convened a series of meetings meant to address hawking in the metro. There a metro spokesman portrayed hawkers as a menace who 'are seeking to take personal advantages' and profit from the use of public space, while they 'do not mention that their objects are not certified and the passengers, being ignorant of this, are being deceived'. ${ }^{2}$ Ultimately, he argued that the enforcement of anti-hawking regulations required a concerted effort from multiple public agencies:

Tehran's metro is expanding and day by day the number of passengers in the metro increases. This increase should go hand in hand with understanding social pathologies related to it. Otherwise, this will lead to a much more complex problem and [will]

2 http://metro.tehran.ir/default.aspx?tabid=398\&ArticleId= ${ }_{1533}$ (Authors' translation) $($ accessed I7 March 20I5). 
gradually increase the insecurity of citizens and ultimately create an unpleasant image of the metro in the capital city. ${ }^{3}$

It is important to recognise that hawkers are considered a 'social pathology' not because they threaten the social fabric of society or an imagined national community. They pose an immediate threat to the embodiment of the state's representation of Tehran. The resilience of hawkers in the metro is particularly threatening because it cannot be eradicated through the transformation of space given the fact that it takes place within the very space that ostensibly represents the city's progress. In a recent move, the authorities have shifted their attention away from the hawkers and started 'educating' passengers about the threats posed by hawkers. This message is delivered on the monitors in the carriages, in public service announcements that accuse hawkers of disturbing the peace and of selling low-quality products that could pose a health risk, and concludes with a plea to passengers to boycott hawkers operating in the metro. The authorities' inability to significantly restrict hawkers from operating in the metro has thus led them to enlist 'the public' (i.e. passengers) in their effort to police public space. We demonstrate in the following section that rather than mobilising passengers, the portrayal of hawkers as a 'social pathology' may have the opposite effect and encourage civil disobedience among passengers, despite reinforcing deeply held notions of hawking as a low-class occupation.

The widespread flouting of anti-hawking rules may create anxieties within officialdom, yet the authorities' concerns over maintaining order and showcasing progress are not echoed by the men who are tasked with actually enforcing antihawking rules. Instead, their complaints revolve around everyday preoccupations of status and livelihood. Only one security guard agreed to be interviewed, but his comments were telling. He explained that the hawkers:

earn a lot of money, they earn I,ooo,ooo toman per month for a few hours of work a day $^{4}$ and I work I2 hours a day and earn 200-250,000 [toman] per month. They pay for one ticket and enter the metro, then they stay in the metro the whole day. You say something to them and they scream and throw themselves in front of the train. You see how bad things have become? We are not really doing anything against them. Sometimes we are a bit harsher, other times we are softer, but we don't take serious action. (Personal communication, 2014)

He explained that the extent to which security guards are 'harsh' or 'soft' is contextual and related to the perceived class position of the woman in question. According to this guard, women who earn a handsome profit are dealt with more strictly, while women who appear to be struggling to provide for themselves and their

3 Ibid.

4 I,Ooo,ooo toman is equivalent to approximately 200 GBP. 
families are typically given a warning. Hawkers from well-heeled backgrounds seem able to respond more effectively to demand, and sell their products to more affluent passengers. While quantitative data would be needed to confirm this definitively, observational research suggested that hawkers from low-class backgrounds tend to sell cheaper items (i.e. gum and candy, cookies, etc.) while those whose appearance indicated a more affluent background sold items such as clothing and toys. Thus, class backgrounds are reinforced, as women from affluent backgrounds are able to earn more money, and this provokes resentment from security guards.

\section{Belonging and governance in Tehran's metro}

Street hawking has historically been considered a low-class occupation in Tehran, so many women struggle to reconcile their work as hawkers with their assertion of a middle-class identity. Crossa (2016) demonstrated that street hawkers in Mexico City cannot be considered a homogenous group, and they actively assert their identity which is determined largely by where they operate in the city. Hawkers in Tehran's metro seek to construct their identity but are also subject to competing pressures. Since Tehran's metro affords women the possibility to enhance their economic independence, this space is emancipatory when analysed from an economic perspective. With regard to belonging and exclusion, however, working as a hawker has fostered anxiety among women whose membership of the middle class is a cornerstone of their identity. These women are faced with a difficult choice between enhanced economic independence and maintaining their class position.

The competing pressures that female hawkers must navigate on an everyday basis are compounded by multiple governance regimes which regulate space within the metro. Schindler (2014a) demonstrated that street hawkers in Delhi are subjected to multiplicities of governance regimes; the city is slowly but inexorably transformed, but on an everyday basis many spaces remain beyond the reach of the municipal authorities. Similarly, Ismail has argued that 'there are multiple orders of state, with their rules and laws perpetually criss-crossing, contingent and situational' (20 I , 855). The case of Tehran is significant because it shows that even flagship projects which are meant to symbolise the transformation of the city are governed by a multiplicity of governance regimes. The most visible governance regime in Tehran's metro is imposed 'from above' by municipal officials and the metro authorities, and its objective is to develop a world-class transportation system to facilitate the circulation of millions of urban residents on a daily basis. Importantly, in line with the ruling elite's conceptualisation of femininity, the space must be arranged in such a way that women travelling unaccompanied by a male relative can move throughout the city without compromising their virtue. This is what makes this space difficult to police, however, as male security guards are restricted from entering the carriages reserved for women. The 
contradictory agenda of facilitating the circulation of people alongside the imperative of securing female virtue has facilitated the emergence of space which is challenging for the authorities to regulate. Unlike their superiors, many of the security guards tasked with regulating space within the metro are not motivated by ensuring that the metro is consistent with world-class aesthetics. Instead, their practice of regulating space is guided by everyday ethics geared towards disciplining those deemed affluent while turning a blind eye to hawkers earning a modest livelihood.

A range of actors seek to influence the governance of urban space, and the contestations that unfold across a range of spaces are highly contextual (Lindell, 2008). When a security guard identifies a woman as a hawker, an intense negotiation commences in which she seeks to persuade him not to lodge a formal case and allow her to leave with her wares. In other words, when hawkers are caught by security the outcome is contingent on whether she is able to convince him that she is in legitimate financial distress. Security guards commonly make decisions about how and when to enforce the law according to an everyday ethics that adjusts punishment according to the perceived social standing of the hawker. The security guard who was interviewed in the course of this research suspected that some female hawkers were earning handsome livelihoods, which provoked his resentment, while he claimed that women who earned subsistence livelihoods were often given a warning. Thus there is an economic incentive for women to portray themselves as financially distressed because women from modest backgrounds are less likely to be disciplined by security guards. Meanwhile, there is a countervailing pressure on female hawkers to portray themselves as middle-class given the stigma attached to hawking. Finally, the space within the women's carriages is self-governed and negotiated. Hawkers seek to respect the space of passengers who may find their presence bothersome, while passengers typically inform hawkers when security personnel are operating at a particular station.

This research demonstrates that far from necessarily expanding highly regulated space, ambitious initiatives of urban transformation are commonly subverted as informal-sector workers can appropriate and use so-called 'world-class' spaces on an everyday basis. The objective transformation of space does, however, induce behavioural changes as people adapt to their newfound environment. The demographic of hawkers operating within the metro is undeniably more affluent than counterparts working in Tehran's bazaars and on its streets. More research is required to determine whether world-class space is more easily appropriated by privileged sections of society. This would mean that while municipal governments may struggle to regulate space in the context of urban transformation, these ambitious programs of city-making nevertheless tend to create spaces for everyday politics of the middle classes. Despite the challenges that female hawkers face in constructing and maintaining their identity, it is important to emphasise that their actions contribute to the transformation of the carriages reserved for women in Tehran's metro into a convivial public space. 


\section{Conclusion: defiance and solidarity}

Capital is remaking cities around the world (Smith, 2002). Urban space in the global North has witnessed the proliferation of privately owned spaces of consumption and leisure, where a sanitised and predictable 'community' - rather than 'public' - is prohibited from engaging in political dissent (Staeheli and Mitchell, 2006; Mitchell and Staeheli, 2005). In contrast to the slow but inexorable erosion of public space in the North, urban transformation in the South is often more dramatic and contested because of the extreme socio-spatial inequality that characterises many cityscapes. Capital is channelled into the built environment and islands of well-connected and privately owned space emerge and sit uncomfortably next to informal settlements. Scholarship has portrayed the relationship between these types of space as zero-sum, and indeed the expansion of the former directly threatens those who live and work in the latter. We have sought to complicate this narrative by asking whether urban space that is transformed remains permanently inaccessible to informal-sector workers. We have focused on female hawkers in Tehran's metro because this latter is heralded as a symbol of the city's claims to world-class status. Everyday space within Tehran's metro is ultimately a product of competing social pressures which the hawkers must navigate and conflicting logics of governance.

Tehran's metro is a symbol of the city's progress and its rapid expansion has served to produce a significant amount of space that is relatively easily appropriated by female hawkers. These women sell a variety of items in the relative safety of the metro to augment their household income or simply earn pocket money. They operate despite the efforts of the authorities to police the metro because most of the security guards are male and prevented from entering the women's carriages. Thus, enforcement is most intense on the platforms, where security guards scrutinise women as they board and disembark the trains. Hawkers disguise themselves as passengers by hiding their goods in shopping bags, and operate with the assistance of passengers who warn them of security crackdowns at particular stations. Passengers participate in the cat and mouse game between security personnel and hawkers because the hawkers provide a valued service, they contribute to the production of convivial public space within the metro and, most importantly, they act in defiance of the authorities. This stands in stark contrast with the relationship between hawkers and middle-class residents in other cities, such as Mumbai (Anjaria, 2009) and Shanghai (Orum et al., 2009). Members of Tehran's progressive middle class tend to consider this assistance a relatively safe act of defiance against authoritarian elements of the country's leadership. The assistance provided by passengers to facilitate female hawkers' operation in Tehran's metro is an example of how the restrictive political atmosphere has produced atomised and calculated acts of resistance in response to the state's aggressive crackdown against any organised oppositional politics. 
The informal and ad hoc collaboration between hawkers and passengers has inhibited the production of a chaste and docile community of Iranian women, much to the consternation of the authorities. In other words, municipal authorities have thus far been unable to police women in the metro, and their acts of defiance - from hawking to removal of their headscarves and dancing - are an assertion of individual agency which contributes to the production of community. These acts are examples of what Yiftachel (2015) refers to as 'defensive urban citizenship', and support his assertion that the urban or metropolitan scale is increasingly the arena in which struggles over belonging and exclusion unfold. In this case, membership in an imagined national community is not an issue. Instead, it is the actual use of urban space which serves as the basis of claims to membership in a community, and which confirms that public woman is alive and well today in Tehran (see Orum et al., 2009).

In conclusion, municipal authorities have struggled to regulate urban space in cities with high levels of informal land use and large informal economies, and this article has shown that simply transforming urban space does not necessarily make it easier to control. Competing governance regimes cohere at the micro-scale, and in contrast to the aesthetic concerns of citywide regimes these are informed by everyday politics, ethics and a sense of solidarity through which organic public space can emerge. How and by whom 'world-class' urban space is used is determined to a large extent by micro-level politics that unfold as people navigate a range of competing social, economic and disciplinary pressures. As the widespread disregard of authority in Tehran's metro indicates, the production of 'world-class' space is a contingent process shaped by complex and countervailing factors. Far from forestalling the appropriation of space, urban transformation initiatives can rework the ways in which people understand their identity and relationship with authorities. Ultimately, this indicates that although many cities are being transformed dramatically, the everyday use of newly produced 'world-class' space is contingent on a range of factors, including governance regimes at the micro-scale which are informed by particular ethics, and a multitude of quotidian transgressions. Future research should focus specifically on how urban transformation fosters and forecloses livelihood-generating activities among a range of social groups, and the diverse ways in which various groups appropriate 'worldclass' urban space and to what ends.

\section{Acknowledgements}

We are grateful to Ashraf Amini for her kind assistance during our field research. 


\section{References}

Alexander, P. and Pfaffe, P. (2014) 'Social relationships to the means and ends of protest in South Africa's ongoing rebellion of the poor: the Balfour insurrections', Social Movement Studies, I3, 204-2I.

Allf, H. (2015) 'Profiteers or moral entrepreneurs? Bazaars, traders and development discourses in Almaty, Kazakhstan', International Development Planning Review, 37, 249-67.

Anguelovski, I. (2013) 'From environmental trauma to safe haven: place attachment and place remaking in three marginalized neighborhoods of Barcelona, Boston, and Havana', City E Community, I2, $2 \mathrm{II}-37$.

Anjaria, J. S. (2009) 'Guardians of the bourgeois city: citizenship, public space, and middleclass activism in Mumbai', City $\mathcal{E}^{2}$ Community, 8, 391-406.

Asiedu, A. B., and Agyei-Mensah, S. (2008) 'Traders on the run: activities of street vendors in the Accra Metropolitan Area, Ghana', Norsk Geografisk Tidsskrift-Norwegian Fournal of Geography, 62, I9I-202.

Bakker, K. (2003) 'Archipelagos and networks: urbanization and water privatization in the south', The Geographical fournal, i69, 328-4I.

Bayat, A. (2000) 'From dangerous classes to quiet rebels: politics of the urban subaltern in the global South', International Sociology, I5, 533-57.

Bayat, A. (2010) Life as politics: how ordinary people change the Middle East, Stanford, CA, Stanford University Press.

Bell, J. S., and Loukaitou-Sideris, A. (2014) 'Sidewalk informality: an examination of street vending regulation in China', International Planning Studies, I9, 22 I-43.

Benjamin, S. (2008) 'Occupancy urbanism: radicalizing politics and economy beyond policy and programs', International fournal of Urban and Regional Research, 32, 719-29.

Blokland, T., Hentschel, C., Holm, A., Lebuhn, H. and Margalit, T. (20I5) 'Urban citizenship and right to the city: the fragmentation of claims', International fournal of Urban and Regional Research, 39, 655-65.

Bradlow, B. (2015) 'City learning from below: urban poor federations and knowledge generation through transnational, horizontal exchange', International Development Planning Review, 37, I29-42.

Bunnell, T. (2002) 'Kampung rules: landscape and the contested government of urban(e) Malayness', Urban Studies, 39, I685-70I.

Caldeira, T. P. (2000) City of walls: crime, segregation, and citizenship in São Paulo, Berkeley, CA, University of California Press.

Chatterjee, P. (2004) The politics of the governed: reflections on popular politics in most of the world, New York, NY, Columbia University Press.

Chen, M. and Skinner, C. (20I4) 'The urban informal economy: enhanced knowledge, appropriate policies and effective organization', in S. Parnel, and S. Oldfield (eds) The Routledge handbook on cities of the Global South, London and New York, NY, Routledge, 219-35.

Crossa, V. (2009) 'Resisting the entrepreneurial city: street vendors' struggle in Mexico City's historic center', International Journal of Urban and Regional Research, 33, 43-63.

Crossa, V. (2016) 'Reading for difference on the street: de-homogenising street vending in Mexico City', Urban Studies, 53, 287-301. 
Davis, M. (2007) Planet of slums, London and New York, NY, Verso.

Dupont, V. (201 I) 'The dream of Delhi as a global city', International fournal of Urban and Regional Research, 35, 533-54.

Fadaee, S. (2012) Social movements in Iran: environmentalism and civil society, London and New York, NY, Routledge.

Ferguson, J. (2015) Give a man a fish: reflections on the new politics of distribution, Durham, NC, Duke University Press.

Fernandez, J. E. (2014) 'Urban metabolism of the global South', in S. Parnell and S. Oldfield (eds) The Routledge handbook on cities of the global South, London and New York, NY, Routledge, 597-6i2.

Foucault, M. (2007) Security, territory, population: lectures at the College de France, Basingstoke, Palgrave Macmillan.

Fox, S. (2014) 'Urbanisation as a global historical process: theory and evidence from sub-Saharan Africa', in S. Parnell, and E. Pieterse (eds) Africa's urban revolution, London and New York, NY, Zed Books, 257-83.

Gandy, M. (2004) 'Rethinking urban metabolism: water, space and the modern city', City, 8, $363-79$.

Goodfellow, T. (2013) 'Planning and development regulation amid rapid urban growth: explaining divergent trajectories in Africa', Geoforum, 48, 83-93.

Goodfellow, T. and Smith. A. (2013) 'From urban catastrophe to "model" city? Politics, security and development in post-conflict Kigali', Urban Studies, 50, 3185-202.

Graham, S. and Marvin, S. (200I) Splintering urbanism: networked infrastructures, technological mobilities and the urban condition, London and New York, NY, Routledge.

Harms, E. (2012) 'Beauty as control in the new Saigon: eviction, new urban zones, and atomized dissent in a Southeast Asian city', American Ethnologist, 39, 735-50.

Hsing, Y.-T. (2010) The great urban transformation: politics of land and property in China, Oxford, Oxford University Press.

Ismail, S. (20II) 'Authoritarian government, neoliberalism and everyday civilities in Egypt', Third World Quarterly, 32, 845-62.

Kleibert, J. M. and Kippers, L. (2016) 'Living the good life? The rise of urban mixed-use enclaves in metro Manila', Urban Geography, 37, 373-95.

Li, T. M. (20го) 'To make live or let die? Rural dispossession and the protection of surplus populations', Antipode, 4I, 66-93.

Lindell, I. (2008) 'The multiple sites of urban governance: insights from an African city', Urban Studies, 45, I879-901.

Lindell, I. and Appelblad, J. (2009) 'Disabling governance: privatisation of city markets and implications for vendors' associations in Kampala, Uganda'. Habitat International, 33, 397-404.

McFarlane, C. (201 I) Learning the city: knowledge and translocal assemblage, Oxford, John Wiley \& Sons.

Mitchell, D. and Staeheli, L. (2005) 'Permitting protest: parsing the fine geography of dissent in America', International Fournal of Urban and Regional Research, 29, 796-8I3.

Ong, A. (20 I I) 'Introduction: worlding cities, or the art of being global', in A. Roy and A. Ong (eds) Worlding cities: Asian experiments and the art of being global, New York, NY, John Wiley \& Sons, I-26. 
Orum, A. M., Bata, S., Shumei, L., Jiewei, T., Yang, S. and Thanh Trung, N. (2009) 'Public man and public space in Shanghai today', City E् Community, 8, 369-89.

Pow, C. P. (2016) 'Urban dystopia and epistemologies of hope', Progress in Human Geography, I5, $464-85$.

Qian,J. (2014) 'Performing the public man: cultures and identities in China's grassroots leisure class', City \& Community, I3, 26-48.

Ramkrishnan, K. (2014) 'Disrupted futures: unpacking metaphors of marginalization in eviction and resettlement narratives', Antipode, 46, 754-72.

Robinson, J. (2006) Ordinary cities: between modernity and development, London and New York, NY, Routledge.

Roy, A. (2009) 'Why India cannot plan its cities: informality, insurgence and the idiom of urbanization', Planning Theory, 8, 76-87.

Roy, A. and Alsayyad, N. (eds) (2004) Urban informality: transnational perspectives from the Middle East, Latin America, and South Asia, Lanham, MD and London, Lexington Books.

Sanyal, K. (2007) Rethinking capitalist development: primitive accumulation, governmentality and post-colonial capitalism, New Delhi, Routledge.

Schindler, S. (20I4a) 'A new Delhi every day: multiplicities of governance regimes in a transforming metropolis', Urban Geography, 35, 402-I9.

Schindler, S. (20I4b) 'Producing and contesting the formal/informal divide: regulating street hawking in Delhi, India', Urban Studies, 5I, 2596-6r2.

Schindler, S. (2015) 'Governing the twenty-first century metropolis and transforming territory', Territory, Politics, Governance, 3, 7-26.

Schindler, S. and Kishore, B. (2015) 'Why Delhi cannot plan its 'new towns': the case of solid waste management in Noida', Geoforum, 6o, 33-42.

Shatkin, G. (201 I) 'Planning privatopolis: representation and contestation in the development of integrated mega-projects', in A. Roy, and A. Ong (eds) Worlding cities: Asian experiments and the art of being global, New York, NY, John Wiley \& Sons, 77-97.

Silver, J. (2014) 'Incremental infrastructures: material improvisation and social collaboration across post-colonial Accra', Urban Geography, 35, 788-804.

Simone, A. (2014) Jakarta: drawing the city near, Minneapolis, MN, University of Minnesota Press.

Smith, N. (2002) 'New globalism, new urbanism: gentrification as global urban strategy', Antipode, 34, 427-50.

Soliman, A. M. (2004) 'Tilting at sphinxes: locating urban informality in Egyptian cities', in A. Roy and N. Alsayyad (eds) Urban informality: transnational perspectives from the Middle East, Latin America, and South Asia, Lanham, MD and London, Lexington Books, I7I-208.

Solinger, D. (1999) Contesting Citizenship in urban China: peasant migrants, the state, and the logic of the market, Berkeley, CA, University of California Press.

Staeheli, L. and Mitchell, D. (2006) 'USA's Destiny? Regulating space and creating community in American shopping malls', Urban Studies, 43, 977-92.

Swanson, K. (2007) 'Revanchist Urbanism heads south: the regulation of indigenous beggars and street vendors in Ecuador', Antipode, 39, 708-28.

Turner, S. and Schoenberger, L. (2012) 'Street vendor livelihoods and everyday politics in Hanoi, Vietnam: the seeds of a diverse economy?', Urban Studies, 49, I027-44. 
Watson, V. (2013) 'African urban fantasies: dreams or nightmares?', Environment and Urbanization, 26, 215-3I.

Weinstein, L. (2014) The durable slum: Dharavi and the right to stay put in globalizing Mumbai, Minneapolis, MN, University of Minnesota Press.

Weinstein, L. and Xuefei, R. (2009) 'The Changing right to the city: urban renewal and housing rights in globalizing Shanghai and Mumbai', City $\&$ Community, 8, 407-32.

Xue, D. and Huang, G. (2015) 'Informality and the state's ambivalence in the regulation of street vending in transforming Guangzhou, China', Geoforum, 62, I56-65.

Yiftacchel, O. (2015) 'Epilogue: from "gray space" to equal "metrozenship"? Reflections on urban citizenship', International Fournal of Urban and Regional Research, 39, 726-37. 